\title{
DAUN KERSEN MUNTINGIA CALABURA SEBAGAI ANTIBAKTERI
}

\author{
Topgati Hanif Bamasri \\ Fakultas Kedoktern, Universitas Lampung, Jl. Prof. DR. Ir. Sumatri Brojonegoro No.1, Gedong Meneng, \\ Kec. Rajabasa, Kota Bandar Lampung, Lampung, Indonesia 35145 \\ topgatihanif@gmail.com (+6285273057937)
}

\begin{abstract}
ABSTRAK
Daun Kersen Muntingia calabura merupakan daun dari salah satu tanaman herbal yang seringkali digunakan sebagai antibakterial tradisional karena memiliki beberapa efek farmakologis salah satunya yaitu sebagai antibakterial yang dapat membunuh berbagai jenis bakteri. Tujuan dari literature review ini bertujuan untuk mengetahui efek farmakologis daun kersen sebagai antibakterial yang dapat membunuh berbagai jenis bakteri. Penelitian ini menggunakan metode literature review yang terdiri dari 21 artikel Google Schoolar, Elsevier dan PubMed NCBI. Selanjutnta hanya 16 artikel yang digunakan dari tahun 2010 hingga tahun 2020. Berbagai penelitian membuktikan bahwa daun kersen mempunyai efek antibakteril. Kandungan flavonoid, saponin dan tanin pada daun kersen dapat merusak komponen struktur bakteri seperti mendenaturasi protein dinding bakteri, menyebabkan lisis sel dengan cara meningkatkan permeabilitas membran dan menghambat komponen sintesis asam nukleat bakteri.
\end{abstract}

Kata kunci: antibakteri; daun kersen; flavonoid; saponin; tanin

\section{KERSEN LEAVES (MUNTINGIA CALABURA) AS ANTIBACTERIAL}

\begin{abstract}
Kersen leaves (Muntingia calabura) is a leaf from one of the herbs that is often used as a traditional antibacterial because it has several pharmacological effects, one of which is as an antibacterial that can kill various types of bacteria. The purpose of this literature review aims to find out the pharmacological effects of kersen leaves as an antibacterial that can kill various types of bacteria. The study used a literature review method consisting of 21 Google Schoolar, Elsevier and PubMed NCBI articles. Only 16 articles were used from 2010 to 2020. Various studies prove that kersen leaves have antibacterial effects. The content of flavonoids, saponins and tannins in kersen leaves can damage bacterial structure components such as denaturing bacterial wall proteins, causing cell lysis by increasing membrane permeability and inhibiting bacterial nucleic acid synthesis components.
\end{abstract}

Keywords: antibacterial; flavonoids; kersen leaves; saponins; tannins

\section{PENDAHULUAN}

Angka kejadian penyakit infeksi terus meningkat dalam beberapa tahun terakhir. Berbagai penyakit infeksi yang disebabkan oleh bakteri banyak menyerang masyarakat di negara-negara berkembang, termasuk di Indonesia. Berbagai macam bakteri dapat menyebabkan penyakit infeksi seperti bakteri Staphylococcus aureus yang dapat menyebabkan infeksi berat pada manusia yang terjadi baik di komunitas maupun rumah sakit. (Radji, 2011).

Pemanfaatan bahan alam sebagai obat tradisional semakin meningkat di Indonesia. Beberapa obat bahan alam telah banyak diproduksi dalam skala 
besar. Penggunaan obat bahan alam dinilai mempunyai efek samping yang lebih rendah dibandingkan obat yang berasal dari bahan kimia, serta memiliki harga lebih terjangkau (Handayani, 2016).

Indonesia adalah salah satu negara tropis yang terkenal dengan keberagaman tumbuhanya yang dapat digunakan sebagai bahan obat. Bagian tumbuhan yang dapat dimanfaatkan sebagai bahan obat antara lain daun, buah, batang, akar dan bunga (Arum, 2012). Salah satu tanaman berkhasiat yang banyak ditemukan di Indonesia adalah Kersen (Muntingia calabura). Kersen (Muntingia calabura) merupakan tanaman tahunan yang dapat tumbuh mencapai ketinggian 10 meter. Batang tanaman kersen berkayu, tegak bulat dan percabangannya simpodial. Kersen memiliki beberapa bagian seperti daun, batang, bunga dan buah (Prasetyo et al., 2014).

Tanaman kersen mempunyai beberapa bagian seperti batang, daun, buah dan bunga (Prasetyo et al., 2014). Kersen (Muntingia calabura) adalah tanaman yang telah lama dimanfaatkan masyarakat sebagai obat tradisional untuk mengobati berbagai penyakit seperti sakit kuning, asam urat, batuk, dan antibakteri (Puspitasari, 2017).

Negara Indonesia, India, Meksiko dan Filipina, secara tradisional penduduknya menggunakan air rebusan daun kersen sebagai antiseptik (Handayani, 2016). Aktivitas antibakteri pada daun Kersen ini disebabkan oleh adanya kandungan senyawa flavonoid, saponin, dan tanin yang dimilikinya. Daun Kersen juga memiliki aktivitas antibakteri, antioksidan dan antipoliferatif (Manik et al., 2014). Melalui pendekatan tersebut dapat diasumsikan bahwa dalam daun kersen terkandung senyawa antimikroba.

Berdasarkan hasil penelitian menunjukan bahwa daun kersen dapat dimanfaatkan sebagai antidiabetes dan memiliki efek yang mampu menghambat aktivitas bakteri penyebab penyakit karena diduga mengandung senyawa flavonoid. Flavonoid adalah golongan terbesar senyawa fenol alam dan juga merupakan senyawa polar karena memiliki sejumlah gugus hidroksil, sehingga akan terlarut dalam pelarut polar seperti metanol dan etanol. Flavonoid adalah senyawa aktif yang dapat bermanfaat sebagai antiinflamasi, antioksidan, dan antibakteri karena memiliki efek yang mampu menghambat aktivitas bakteri penyebab penyakit (Arum, 2012).

Berdasarkan latar belakang yang menyebutkan bahwa daun kersen dapat mempunyai efek farmakologis sebagai antibakteri serta banyak dimanfaatkan secara empirik oleh masyarakat Indonesia maka akan diteliti potensi antibakteri terhadap berbagai jenis bakteri. Tujuan dari artikel ini adalah untuk mengetahui potensi antibakteri ekstrak daun kersen (Muntingia calabura) terhadap berbagai bakteri penyebab infeksi, sehingga dapat menjadikan daun kersen (Muntingia calabura) sebagai obat antibakteria alamiah dan jenis penelitian ini berbeda dengan penelitian lain karena artikel ini menggunakan metode literature review.

\section{METODE}

Pada penulisan ini menggunakan metode studi artikel review. Sumber pustaka yang digunakan yaitu berasal dari penelitian-penelitian dan bukubuku pedoman mengenai efektivitas dan senyawa kimia yang terkandung di dalam daun tanaman kersen (Muntingia 
calabura) yang diterbitkan pada tahun 2010 hingga tahun 2020 dan dapat diakses melalui internet di Google Scholar, PubMed, elseiver dan NCBI. Dari 16 artikel tesebut kemudian di analisis menggunakan metode Systematic Literature Review yaitu dengan mengumpulkan, mengevaluasi, dan mengembangkan penelitian pada fokus topik tertentu.

\section{HASIL}

Pada penelitian Handayani tahun 2016, uji aktivitas antibakteri dilakukan menggunakan metode difusi agar. Hasil penelitian membuktikan bahwa ekstrak etanol daun kersen mempunyai kemampuan menghambat aktivitas pertumbuhan bakteri Staphylococcus Epidermidis pada konsentrasi 1ppm, 3ppm, 5ppm, 9ppm. Ekstrak etanol daun kersen memiliki pengaruh yang efektif dalam menghambat pertumbuhan Staphylococcus epidermidis (Handayani, 2016). Pada penelitian lain juga menunjukan hasil uji efektivitas antibakteri sabun cair ekstrak etanol daun Kersen mempunyai efektivitas antibakteri terhadap bakteri Staphylococcus epidermidis (Korompis et al., 2020).

Berdasarkan penelitian Arum tahun 2012 menggunakan ekstrak etanol dan metanol disimpulkan hasil isolasi daun kersen. Berdasarkan hasil penelitian ini menunjukan bahwa hasil isolasi daun kersen dengan menggunakan ekstrak etanol dan metanol mempunyai potensi antibakterial. Senyawa flavanoid yang diperoleh merupakan jenis senyawa flavonol, flavon, dan auron. Ekstrak etanol dan metanol memiliki potensi antibakteri terhadap bakteri Pseudomonas aeruginosa, Eschericia coli, Staphylococcus aureus dan Bacillus subtilis dengan semakin tinggi konsentrasi maka daya hambat semakin besar (Arum, 2012).

Pada penelitian Nadifah dkk tahun 2018 dengan metode modified Kirby-Bauer technique membuktikan, dari hasil penelitian dibuktikan bahwa infusa daun kersen mempunyai daya hambat pada pertumbuhan bakteri Klebsiella pneumoniae dari hasil isolasi pasien infeksi saluran kemih. Meskipun zona hambat yang dibentuk infusa menunjukan lebih kecil dari zona hambat oleh antibiotik chloramphenicol, meropenem dan cefotaxime, namun dengan potensi ini dapat dikembangkan sebagai alternatif pengobatan dengan antibiotik yang diketahui dapat menimbulkan efek samping (Nadifah et al., 2018).

Pada penelitian sobirin tahun 2018 tentang uji aktivitas antibakteri ekstrak etil asetat daun kersen (Muntingia calabura) terhadap bakteri Salmonella typhi menggunakan metode difusi agar Kirby Bauer. Semakin besar konsentrasi ekstrak, semakin besar pula zona hambat yang terbentuk. Hasil penelitian menunjukan adanya daya hambat bakteri Salmonella typhi. Ekstrak dengan konsentrasi yang tinggi mengandung senyawa aktif dengan kadar yang tinggi, sehingga lebih besar daya hambatnya (Sobirin, 2018).

Pada penelitian Sulaiman Yusuf dkk tahun 2017 membuktikan hasil bahwa ekstrak daun kersen (Muntingia calabura) mempunyai kandungan senyawa antibakteri seperti flavonoid, saponin dan tanin yang diujikan terhadap pertumbuhan Streptococcus viridans. Konsentrasi senyawa ekstrak daun kersen yang mempunyai daya hambat terbesar terhadap pertumbuhan Streptococcus viridans adalah 
konsentrasi $75 \%$ (Sulaiman et al., 2017).

\section{PEMBAHASAN}

Antibakteri adalah suatu zat yang berfungsi mengganggu pertumbuhan atau mematikan bakteri dengan cara mengganggu metabolisme bakteri yang merugikan. Mekanisme kerja dari senyawa antibakteri diantaranya yaitu menghambat sintesis pembentkan dinding sel, menghambat keutuhan permeabilitas dari dinding sel bakteri, menghambat kerja enzim dan menghambat komponen sintesis asam nukleat dan protein (Boopathi et al., 2017).

Senyawa kimia yang terkandung dalam ekstrak daun kersen (Muntingia calabura) mempunyai beberapa manfaat diantaranya yaitu sebagai antibakteri. Potensi tersebut dimanfaatkan dalam rangka mencegah atau mengobati penyakit infeksi. Aktivitas antibakteri pada infusa daun kersen dikarenakan adanya kandungan senyawa-senyawa antibakteri seperti flavonoid, saponin, dan tanin. (Kurniawan et al., 2010).

Senyawa flavonoid pada daun kersen melepaskan energi tranduksi terhadap membran sitoplasma bakteri serta menghambat motilitas bakteri. Mekanisme kerjanya dengan cara mempengaruhi fungsi sel yaitu mendenaturasi protein sel yang terdapat pada dinding sel bakteri akan terhambat (Zakaria et al. ,2010). Senyawa saponin sebagai zat aktif, dapat meningkatkan permeabilitas membran sel bakteri sehingga menyebabkan lisis sel. Apabila saponin bereaksi dengan sel bakteri maka menyebabkan bakteri tersebut akan lisis atau pecah (Hidayah et al., 2018).
Senyawa tanin berinteraksi dengan cara membentuk senyawa kompleks polisakarida yang dapat merusak dinding sel bakteri sehingga permeabilitas sel bakteri menjadi terganggu. Permeabilitas sel bakteri yang terganggu tersebut menyebabkan sel tidak dapat menjalankan aktivitas hidup, akibatnya pertumbuhan bakteri akan terhambat dan menyebabkan bakteri mati. Selain dengan merusak dinding sel bakteri, tanin juga dapat mendenaturasi protein dan menghambat komponen sintesis asam nukleat bakteri (Mukhlishoh, 2017).

Pada penelitian arum dkk menggunakan ektrak etanol dan metanol daun kersen menunjukan hasil ekstrak metanol mempunyai aktivitas daya hambat terhadap bakteri yang lebih besar dibandingkan dengan ekstrak etanol yaitu daya hambat terhadap bakteri Eschericia coli dan Staphylococcus aureus. Fraksi etanol dan metanol yang memiliki kepekatan yang paling tinggi berdaya hambat terhadap bakteri lebih besar sehingga mempunyai diameter hambat yang lebih luas, sedangkan fraksi etanol dan metanol yang memiliki kepekatan yang paling rendah menunjukkan hasil daya hambat yang kecil. Hal ini disebabkan karena semakin besar kadar senyawa bioaktif maka semakin bersifat bakterisida (agen mematikan mikroba), sedangkan kadar yang lebih kecil biasanya hanya bersifat bakteriostatik (agen yang hanya menghambat pertumbuhan mikroba, tidak mematikan mikroba) (Sekar \& Jalil, 2017).

Pada beberapa uji fraksi ditunjukan hasil fraksi heksan $>40 \mathrm{mg} / \mathrm{mL}$, fraksi air 2,5 $\mathrm{mg} / \mathrm{mL}$, ekstrak etanol 1,25 $\mathrm{mg} / \mathrm{mL}$ serta fraksi etil asetat 0,312 $\mathrm{mg} / \mathrm{mL}$. Fraksi etil asetat mempunyai aktivitas antibakteri paling besar dengan 
kadar bunuh minimum (KBM) sebesar $0,312 \mathrm{mg} / \mathrm{mL}$. Kandungan flavonoid total mempengaruhi besarnya aktivitas antibakteri. Sebesar 93\% aktivitas anti bakteri dipengaruhi oleh kandungan flavonoid total yang menunjukkan semakin besar kandungan flavonoid totalnya, maka semakin tinggi juga aktivitas antibakterinya (Manik et al., 2014).

\section{SIMPULAN}

Kandungan flavanoid, tanin dan saponin yang terdapat pada daun kersen (Muntingia calabura) bermanfaat sebagai agen antibakteri dengan mekanisme kerja yaitu mendenaturasi protein sel pada struktur dinding sel bakteri, menyebabkan lisis sel dengan meningkatkan permeabilitas membran sel serta mendenaturasi protein dan menghambat sintesis komponen asam nukleat bakteri.

\section{DAFTAR PUSTAKA}

Radji M. (2011). Buku ajar mikrobiologi panduan mahasiswa farmasi dan kedokteran. EGC. Jakarta.

Prasetyo, A. D., Sasongko, H., Iii, K., \& Soepomo, J. P. (2014). Aktivitas antibakteri ekstrak etanol $70 \%$ daun kersen ( Muntingia Calabura $L$.) terhadap bakteri Bacillus subtilis dan Shigella dysenteriae. JUPEMASI-PBIO, 1(1), 98-102.

Handayani, V. (2016). Pengujian aktivitas antibakteri ekstrak etanol daun kersen (Muntingia Calabura L.) terhadap bakteri penyebab jerawat. Jurnal Fitofarmaka Indonesia, 2(1), 94-96. https://doi.org/10.33096/jffi.v2i1. $\underline{186}$

Boopathi, T., Gopalasatheeskumar, K.,
Parthiban, S., Sangeetha, G., Kokila, M. T., \& Manimaran, T. (2017). Evaluation of antimicrobial activity of tecoma stans and muntingia calabura. World Journal of Pharmaceutical Research, 6(3), 617-627. https://doi.org/10.20959/wjpr2017 3-7820

Handayani, V. (2016). Pengujian aktivitas antibakteri ekstrak etanol daun kersen (Muntingia Calabura l.) terhadap bakteri penyebab jerawat. Jurnal Fitofarmaka Indonesia, 2(1), 94-96. https://doi.org/10.33096/jffi.v2i1. 186

Hidayah, M., Oktavia, R., \& Krihariyani, D. (2018). ( Muntingia calabura $L$. ) Terhadap pertumbuhan bakteri Salmonella $s p$ metode dilusi cair. 7(2), 618-623.

Korompis, F. C. C., Yamlean, P. V. Y., \& Lolo, W. A. (2020). Formulasi dan uji efektivitas antibakteri sediaan sabun cair ekstrak etanol daun kersen (Muntingia Calabura L.) terhadap bakteri Staphlococcous epidermidis. Pharmacon, 9(1), 30-37.

Kurniawan, I., Sarwiyono, \& Surjowardojo, P. (2010). Pengaruh teat dipping menggunakan dekok daun kersen (Muntingia calabura L.) terhadap tingkat kejadian mastitis. JurnalJurnal Ilmu Peternakan, 23(3), 27-31.

Manik, D. F., Hertiani, T., \& Anshory, H. (2014). Analisis korelasi antara kadar flavonoid dengan aktivitas antibakteri ekstrak etanol dan fraksi-fraksi daun kersen (Muntingia calabura L.) terhadap 
Staphylococcus aureus. Khazanah, 6(2), 1-11. https://doi.org/10.20885/khazanah .vol6.iss2.art1

Nadifah, F., Arisandi, D., Fatimah, S., \& Setiawan, D. (2018). Ekstrak air daun talok dalam menghabat pertumbuhan bakteri Klebsiella pneumoniae. Jurnal Nasional Teknologi Terapan, 2(3), 223229.

Prasetyo, A. D., Sasongko, H., Iii, K., \& Soepomo, J. P. (2014). Aktivitas antibakteri ekstrak etanol $70 \%$ daun kersen ( Muntingia Calabura $L$.) terhadap bakteri Bacillus subtilis dan Shigella dysenteriae. JUPEMASI-PBIO, l(1), 98-102.

Sekar, M., \& Jalil, N. S. A. (2017). Formulation and evaluation of novel antibacterial and antiinflammatory cream containing Muntingia calabura leaves extract. Asian Journal of Pharmaceutical and Clinical Research, 10(12), 376-379. https://doi.org/10.22159/ajpcr.201 7.v10i12.21963

Sobirin, M. (2018). Uji efektivitas anti mikroba ekstrak daun kersen. Jurnal Borneo Cendekia, 2(2), 253-261.

Sulaiman, A. Y., Astuti, P., Dewi, A., Shita, P., Yusuf, A., Fakultas, S., Gigi, K., Mengutip, C., Sulaiman, :, Astuti, A. Y., Shita, P., Ekstrak, U. A., \& Kersen, D. (2017). Uji antibakteri ekstrak daun kersen (Muntingia Calabura L.) terhadap koloni Streptococcus viridians. Indones. J. Heal.Sci, 01(02), 1-7.

YP Arum, Supartono, S. (2012). Isolasi dan uji daya antimikroba ekstrak daun kersen (Muntingia calabura). Jurnal MIPA, 35(2), 165-174.

Zakaria A.Z. (2010). In vitro antimicrobial activity of Muntingia calabura extracts and fractions. African Journal of Microbiology Research, 4(4), 304-308. 